\title{
Relationship between bacterial community profile in biofilm and attachment of the acorn barnacle Balanus amphitrite
}

\author{
Pei-Yuan Qian*, Vengatesen Thiyagarajan, Stanley Chun Kwan Lau, Sam Chi Kin Cheung \\ Department of Biology/Coastal Marine Laboratory, The Hong Kong University of Science and Technology, \\ Clear Water Bay, Kowloon, Hong Kong SAR
}

\begin{abstract}
The relationship between bacterial community profile in biofilm and attachment of the acorn barnacle Balanus amphitrite was investigated using a double-dish choice larval attachment bioassay and the DNA fingerprinting technique T-RFLP (terminal-restriction fragment length polymorphism). Biofilms for bioassays were either developed at 3 intertidal heights (i.e. high, mid and low) for $6 \mathrm{~d}$ or at the mid-intertidal height for 3 to $12 \mathrm{~d}$. A clear distinction among biofilm communities at the 3 intertidal heights was revealed in the bacterial community profiles (determined by $\mathrm{T}$ RFLP), biomass (determined by total organic carbon analysis), and abundance of bacteria and diatoms. Overall, cyprids of $B$. amphitrite preferred intertidal biofilms (i.e. $6 \mathrm{~d}$ old) over unfilmed surfaces for attachment. Moreover, cyprids also preferred to attach on biofilms of mid-intertidal height over high-intertidal or subtidal heights. There was no correlation between cypris attachment and any of the 3 biofilm attributes (i.e. biomass, abundance of bacteria and diatoms). Therefore, it was concluded that changes in the bacterial community profile in the biofilm affect the attractiveness of the biofilm to barnacle larvae and, thus, may determine the behavior (accepting or rejecting a surface) of settling larvae. We hypothesize that the temporal and spatial changes in the microbial community profile lead to the temporal and spatial recruitment pattern of marine invertebrates at a microscopic scale.
\end{abstract}

KEY WORDS: Balanus amphitrite $\cdot$ Cypris attachment $\cdot$ Intertidal biofilm $\cdot$ Microbial community Terminal-restriction fragment length polymorphism $\cdot$ T-RFLP

Resale or republication not permitted without written consent of the publisher

\section{INTRODUCTION}

Habitat selection by cyprids (referred to as 'cypris attachment') may play a key role in determining the temporal and spatial recruitment pattern of barnacles, as suggested by previous field studies (e.g. Strathmann et al. 1981, Minchinton \& Scheibling 1993). The habitat selection process is likely to be influenced by various factors such as the presence of conspecifics (Jeffery 2002), the substratum properties (Wahl \& Hoppe 2002), the environment in which larvae develop (Holm et al. 2000), the physiological condition of cyprids (Thiyagarajan et al. 2002), and the microbial community (Olivier et al. 2000). Among them, the influence of microbial community on cypris attachment has been poorly investigated.
Submerged surfaces in the marine environment are rapidly covered with complex agglomerates of microorganisms (mainly bacteria and diatoms) and organics referred to as biofilm. The microbial components of biofilm, especially bacteria, are sensitive to changes in environmental parameters; thus, the physiology and composition of the bacterial community in biofilm can reflect the local environmental conditions of a substratum (Wieczorek et al. 1996 and references therein). Sessile invertebrate larvae are able to distinguish between biofilms of varying composition, physiological condition and growth phase (reviewed by Wieczorek \& Todd 1998), suggesting that microorganisms therein serve as an important indicator for larvae seeking a suitable substratum. It has been suggested that intertidal barnacles can possibly identify the tidal height by 
detecting variation of biofilm components along the intertidal zone (Strathmann et al. 1981, Thompson et al. 1998, Miron et al. 1999). Ephemeral algae guide Semibalanus balanoides to attach along the high intertidal region (Minchinton \& Scheibling 1993). Moreover, the highly absorptive property of biofilms may also guide cyprids by absorbing settlement factors leached from conspecific adults which they can identify (Henschel \& Cook 1990). Therefore, the exploration of biofilms allows cyprids to assess the suitability of an environment for post-settlement survival.

The influence of biofilm on the attachment of Balanus amphitrite, a dominant fouler and an important rocky-shore mid-intertidal organism, has been examined in several studies (Maki et al. 1988, Wieczorek et al. 1995, Tsurumi \& Fusetani 1998, Harder et al. 2001). However, all these studies were conducted with subtidal biofilms exclusively. Our understanding of the relationship between intertidal biofilm characteristics and the attachment of $B$. amphitrite was, therefore, derived largely from the field study of Olivier et al. (2000), which concluded that cyprids preferred unfilmed over biofilmed surfaces and were incapable of distinguishing the biofilms from 3 intertidal heights. Several previous studies have tried to correlate cypris attachment of $B$. amphitrite to bacterial community in the biofilm by using monocultures of bacteria isolated from biofilms (e.g. Maki et al. 1988, Homstrom et al. 1992, Avelin Mary et al. 1993, O'Connor \& Richardson 1996, Lau et al. 2003). However, this approach has never been comprehensive, since only $<5 \%$ of bacteria in the biofilm is cultivable.

More importantly, bacterial abundance was commonly used as a descriptor of biofilm in previous studies on the relationship between biofilm age/quality, and its bioactivity for larval settlement induction and inhibition (e.g. Maki et al. 1988, Olivier et al. 2000). The spatial and temporal changes in micro-organism (diatoms, bacteria, fungi and so on) compositions of the biofilm have not been investigated. Consequently, the relationship between biofilm dynamics and biofilm bioactivity on larval attachment and metamorphosis has never been addressed. With well-established molecular methods (i.e. culture-independent), we can illustrate bacterial community profile in virtually any habitat (Osborn et al. 2000, Steinberg et al. 2002). For instance, the bacterial community profile in marine biofilms on soft coral surfaces and rocky substratum has been recently studied (Harder et al. 2003). A correlation between bacterial diversity in biofilm and larval attachment will certainly provide insight into the significance of biofilm as mediators for larval attachment.

In the field, cypris attachment is influenced by a range of physico-chemical factors, of which many are unknown to the investigators; for example, cypris age, larval supply and cyprid exploration of the offered choices ('perception distance') (see Wieczorek \& Todd 1998). Although laboratory bioassays can neither mimic the complexity of the natural environment, especially the water flow patterns, nor take into account all of the complex interactions affecting the habitat-selection process in the field, the bioassays can greatly reduce the interference of factors such as the presence of conspecifics, larval supply, variation of cypris age and physiological condition during attachment, and thus facilitate the interpretation of the results (e.g. Hudon et al. 1983, Thompson et al. 1998).

In this study, we characterized the temporal and spatial variations of biofilm structures developed over periods of different lengths at different tidal heights in the natural environment. The parameters measured were total biomass, diatom and bacterial abundance, and bacterial community profile revealed by terminal-restriction fragment length polymorphisms (T-RFLP) analysis of PCR-amplified 16S rRNA extracted from biofilm. We also examined the cypris attachment of Balanus amphitrite on the biofilms developed at different tidal heights and habitats for different times (age) by using choice ('biofilmed' versus 'unfilmed') bioassays. The main purpose of our study on biofilms was to elucidate the influence of temporal and spatial changes in bacterial community structures on cypris choice of attachment site.

\section{MATERIALS AND METHODS}

Site description and development of biofilm. Biofilms were developed between September and November 2002 at 2 sites, the Marina Cove and the Hong Kong University of Science and Technology (HKUST) pier, both located in Port Shelter Bay $\left(22^{\circ} 19^{\prime} \mathrm{N}, 114^{\circ} 16^{\prime} \mathrm{E}\right)$ in the eastern Hong Kong waters. Port Shelter Bay is a shallow ( 10 to $15 \mathrm{~m}$ deep), semi-enclosed bay and has semidiurnal tides with an average amplitude of $\sim 2 \mathrm{~m}$. During the study period, salinities generally ranged from 28 to $32 \%$ and temperatures from 24 to $27^{\circ} \mathrm{C}$. Although the 2 sites were separated by only $\sim 1 \mathrm{~km}$, Balanus amphitrite was dominant on the pier of the Marina Cove while rock oysters were abundant on the pier of HKUST.

In the Marina Cove, adult Balanus amphitrite were most abundant at mid-intertidal height (M: 1 $\mathrm{m}$ above mean low-water level, MLWL) (see Fig. 1). They were sparse at high (H: $\sim 1.4 \mathrm{~m}$ above MLWL) and low (L: $\sim 0.6 \mathrm{~m}$ above MLWL) intertidal heights. Usually they do not occur in the subtidal region (e.g. $\sim 3 \mathrm{~m}$ below MLWL) in Hong Kong (Qiu et al. 2003). The tidal height for biofilm development was chosen based on this vertical distribution pattern of $B$. amphitrite adults (see subsequent sections for further details). 


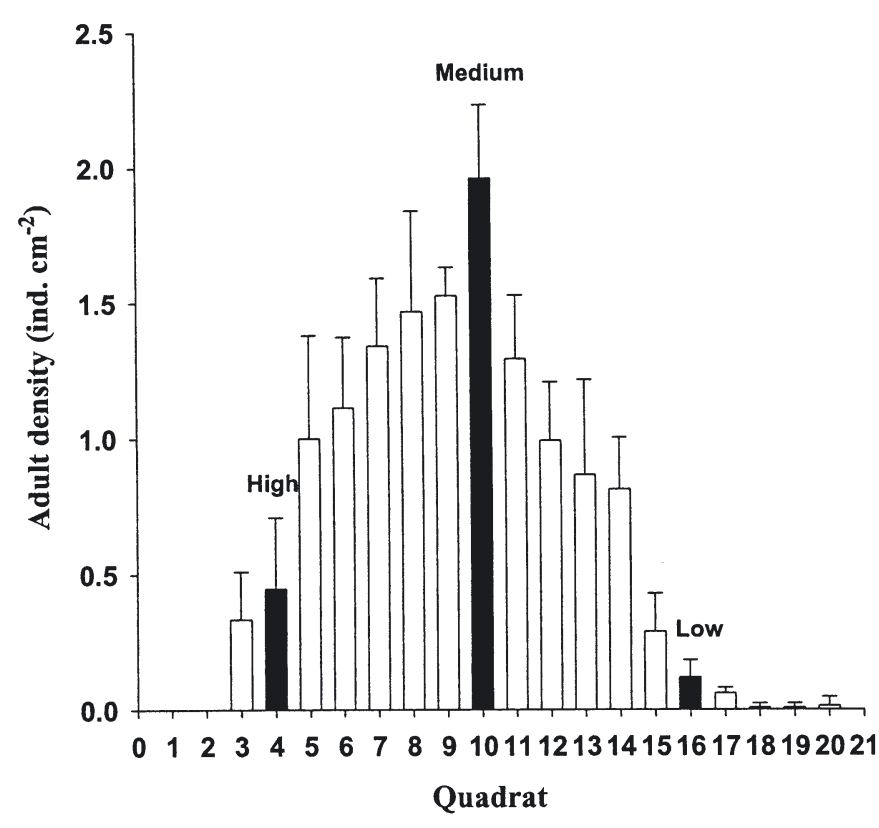

Fig. 1. Balanus amphitrite. Vertical distribution of adults on the piers of Marina Cove, Hong Kong (114 $\left.16^{\prime} \mathrm{E}, 2^{\circ}{ }^{\circ} 9^{\prime} \mathrm{N}\right)$ during September 2002. Data are given as mean $( \pm S D, n=6)$ density of adults counted within contiguous $5 \times 5 \mathrm{~cm}$ quadrates. The starting point was located $\sim 50 \mathrm{~cm}$ below the limit of the high water mark. Counts were stopped $\sim 50 \mathrm{~cm}$ above the low water mark. Solid bars indicate the intertidal heights chosen for the development of biofilms in this study

Biofilms were developed on polystyrene Petri dishes (FALCON \#1006). Dishes were not covered by plankton mesh since the settlement of invertebrates was very low within the $12 \mathrm{~d}$ of immersion. Several $(\mathrm{n}=20$ to 30 ) replicate dishes for the 3 tidal heights were attached vertically to nylon rope; the upper end of the rope was fixed to the pier. This design not only provided ample space between replicate dishes $(\sim 1 \mathrm{~cm})$, but also allowed the rope to rotate with the water current.

Enumeration of bacteria and diatoms in biofilm. Bacteria were visualized after staining with the DNAbinding fluorochrome 4,6-diamidino-2-phenylindole (DAPI, Fluka Chemie) and counted using epifluorescent microscopy at a magnification of $1250 \times$ in 10 randomly chosen fields of view (ZEISS Axiophot fluorescence microscope, $\left.\lambda_{\mathrm{Ex}}=359 \mathrm{~nm}, \lambda_{\mathrm{Em}}=441 \mathrm{~nm}\right)$, as described in Lau et al. (2003). Abundance of diatoms was calculated using a light microscope at a magnification of $400 \times$.

Estimation of biofilm biomass. Biofilms without staining $\left(\sim 20 \mathrm{~cm}^{2}\right)$ were scrapped from dishes using a nylon brush to estimate total organic carbon (TOC), a measure of biomass. Samples were homogenized by exposure to ultrasonic pulses (Branson Sonifier 450) and analyzed for TOC by high-temperature catalytic oxidation at $680^{\circ} \mathrm{C}$ in a Shimadzu TOC- $\mathrm{V}_{\mathrm{CPH} / \mathrm{CPN}}$ analyzer according to manufacturer protocol. Calibration curves were obtained using potassium hydrogen phthalate (for total carbon) and sodium hydrogen carbonate (for inorganic carbon).

Extraction of bacterial community DNA, and PCR. Replicate $(n=3)$ biofilm samples used for Repeat 1 were scraped off dishes $\left(\sim 20 \mathrm{~cm}^{2}\right)$ using sterile glass coverslips. Removed biofilm was suspended in $0.8 \mathrm{ml}$ of lysis buffer $(1 \%$ Triton X-100, $20 \mathrm{mM}$ Tris- $\mathrm{HCl}$ at pH 8, 2 mM EDTA). Bacterial community DNA was extracted and isolated according to Liu et al. (1997). PCR of 16S rRNA genes (rDNA) in the bacterial community DNA was performed in a total volume of $25 \mu \mathrm{l}$, containing $1 \mu \mathrm{l}$ of DNA template, $250 \mu \mathrm{M}$ of each deoxyribonucleotide triphosphate (dATP, dCTP, dGTP, dTTP; Pharmacia Biotechnology), $1 \mathrm{U}$ of buffered AmpliTaq Gold ${ }^{\mathrm{TM}}$ DNA polymerase (Applied Biosystems), $1.5 \mathrm{mM} \mathrm{MgCl}_{2}$, and $1 \mu \mathrm{M}$ of each universal primer: $341 \mathrm{~F}$ (5'-CCTACGGGAGGCAGCAG-3') and 926R-Fam (5'-CCGTCAATTCCTTTRAGTTT-3'). The 926R-FAM was labeled at the 5' end with the phosphoramidite dye 5-hexachlorofluorescein. PCR was performed at: $95^{\circ} \mathrm{C}$ for $10 \mathrm{~min} ; 35$ cycles of $95^{\circ} \mathrm{C}$ for $1 \mathrm{~min}$; $55^{\circ} \mathrm{C}$ for $1 \mathrm{~min} ; 72^{\circ} \mathrm{C}$ for $1 \mathrm{~min}$; and $72^{\circ} \mathrm{C}$ for $5 \mathrm{~min}$. Amplification of DNA was verified by electrophoresis of $5 \mu$ of PCR products in $1.5 \%$ agarose in TAE buffer (40 mM Tris-acetate, 1 mM EDTA, pH 8.0).

T-RFLP analysis. Fluorescently labeled PCR products were digested with $20 \mathrm{U}$ MspI (Boehringer Mannheim Biochemicals) at $37^{\circ} \mathrm{C}$ for $6 \mathrm{~h}$. Digested amplicons were purified with the Wizard ${ }^{\circledR}$ PCR preps DNA purification system (Promega) according to the manufacturer protocol. Aliquots of purified products $(10 \mu \mathrm{l})$ were mixed with $0.5 \mu \mathrm{l}$ of internal size standard (ET-550, Amersham). This mixture was denatured for $5 \mathrm{~min}$ at $95^{\circ} \mathrm{C}$ and immediately chilled on ice before electrophoresis on a MegaBace genetic analyzer (Amersham) operated in Genotyping mode. After electrophoresis, the length of fluorescently labeled terminal-restriction fragments (T-RFs) was determined by comparison with internal standards, using fragment profiler software (Amersham). For each sample, peaks over a threshold of 50 fluorescence were used and terminal fragments $<35$ and $>500$ bp were excluded from the analysis to avoid detection of primers and uncertainties of size determination.

Larval culture. Adult Balanus amphitrite were collected from Marina Cove, Hong Kong, between September and November 2002. After $24 \mathrm{~h}$ of exposure to air, 50 to 200 adults were placed in a container containing $0.22 \mu \mathrm{m}$-filtered seawater (FSW) of 32\% salinity to induce the release of larvae. Nauplii obtained from several adults were reared to cypris stage in batch culture on a diet of Chaetoceros gracilis Schutt 
at $26 \pm 1^{\circ} \mathrm{C}$, according to Thiyagarajan et al. (2002). Newly transformed cyprids (young cyprids) were used in still-water Petri dish assays to determine the percent metamorphosis on surfaces with biofilms developed at different locations and for different periods of time.

Larval bioassay. The attachment response of cyprids was investigated in still-water choice assays (or doubledish assay) according to Harder et al. (2001). The choice was between biofilmed (referred to as 'biofilmed dishes') and unfilmed polystyrene dishes (referred to as 'unfilmed dishes'). Prior to the bioassay, biofilmed dishes were dip-rinsed 10 times in FSW to remove loosely attached biofilm components. Biofilmed dishes that had newly settled barnacles and/or invertebrates during the field submersion were not used for laboratory bioassay. A test vessel was constructed by connecting 2 of these dishes as a single unit (see Harder et al. 2001 for details of test-vessel set up). Briefly, a known number (40 to 50 ind., the attachment was independent of cypris density within this range: O'Connor \& Richardson 1998) of young (0 d old) cyprids was transferred into an unfilmed dish. A tight-fitting PVC ring (inner diameter: $51 \mathrm{~mm}$; width: $6 \mathrm{~mm}$ ) was attached around the dish and subsequently filled with $13.5 \mathrm{ml}$ of FSW. Control vessels were prepared accordingly by connecting 2 unfilmed dishes. Assays were run with vessels mounted in vertical position for $36 \mathrm{~h}$ at $26^{\circ} \mathrm{C}$. At the end of each experiment, the numbers of attached cyprids (both attached and metamorphosed individuals) on the biofilmed and unfilmed dishes, as well as the non-settled ones, were counted.

Recently, the double-dish assay method was employed to determine the cyprids' preference between 2 surfaces (Harder et al. 2001, Lau et al. 2003). Compared to conventional horizontal dish assays, the formation of the organic layer on the water surface, due to bacterial decomposition of organic matter, in the biofilm of double-dish assays (when used as test surface) was substantially reduced as a result of low surface-to-volume ratio, which, in turn, prevented the entrapment of cyprids. In addition, the 2 test surfaces in double-dish assays are separated by only $<2 \mathrm{~cm}$; therefore, cyprids should be capable of exploring both test surfaces before a choice of attachment is made. Thus, limitation of choice for attachment due to low perception distance of cyprids, as pointed out by Wieczorek \& Todd (1998), was unlikely in double-dish assays. Furthermore, the bioassay system used in this study was suitable to preclude the induction of attachment by waterborne cues.

Expt 1. Effects of temporal changes of biofilm (age) on cypris attachment. This experiment consisted of 5 treatments with biofilms developed over 0 (unfilmed control), 3, 6, 9 and $12 \mathrm{~d}$ respectively. Biofilms were developed at the mid-intertidal height at HKUST. Test vessels were constructed with biofilmed and unfilmed dishes. The experiment was repeated 3 times on 24 (Repeat 1), 28 (Repeat 2) and 30 (Repeat 3) September 2002 using larvae obtained from different broodstocks.

Expt 2. Effects of spatial changes of biofilm (developed at 3 different intertidal heights at 2 different sites) on cypris attachment. This experiment consisted of a control vessel and 6 treatments ( $6 \mathrm{~d}$ old biofilms obtained from 3 intertidal heights $\times 2$ sites, Marina Cove and HKUST). Biofilms of these 2 sites were used to establish whether cyprids would settle preferentially on the biofilms developed in the Marine Cove, where a dense conspecific (Balanus amphitrite) population was found. Test vessels were constructed with biofilmed and unfilmed dishes. The experiment was repeated 3 times on 30 September (Repeat 1), 20 October (Repeat 2) and 21 November (Repeat 3) 2002 using larvae obtained from different broodstocks.

Expt 3. Determination of cyprid preference for midintertidal height biofilms. Unlike earlier experiments, the test vessels were prepared by connecting biofilmed dishes from the mid-intertidal height to biofilmed dishes from either the high, low or subtidal origin to investigate preferences. All biofilms were developed over $6 \mathrm{~d}$ at the Marina Cove. The experiment was repeated 3 times during the same period as Expt 2.

Statistical analysis. The T-RFLP patterns were analyzed by visual comparison of the electropherograms and by cluster analysis. The Sorenson or Dice coefficient was calculated based on the total number of $\mathrm{T}$ RFs observed in all samples and the presence or absence of these T-RFs in individual samples. Agglomerative hierarchical clustering was performed using the similarity matrix of Sorenson coefficients, and the simple (unweighted) group average method was displayed as a dendrogram using PRIMER statistical software (Clarke \& Warwick 1994).

Attachment in test and control vessels was compared to the null hypothesis of 50:50 distribution of attached cyprids on either side of the vessel, using replicated $G$-tests for the goodness of fit (Zar 1999). The G-value was calculated as a measure of heterogeneity among replicate vessels within experiment type, as well as among experimental repeats. A total of 15 replicates ( 5 replicates per treatment $\times 3$ experimental repeats) was used for each treatment. Some replicates were, however, omitted from data analysis, since water leaked during larval bioassay. Homogenous data sets were pooled, and corresponding $G$-values were transformed by Williams' correction (Zar 1999). Results of the 5 replicate assays and 3 experimental repeats for each treatment were pooled to carry out Spearman's rank order correlation analysis between attachment and bacterial abundance or diatom abundance or biomass, and between bacterial/diatom abundance and biofilm age or intertidal height. For correlation analy- 
sis, the percent attachment, and abundance of bacteria and diatoms on the biofilmed side (or dish) of a test vessel was used.

\section{RESULTS}

\section{Temporal and spatial changes of bacteria and diatoms in biofilm}

\section{Abundance of bacteria and diatoms}

The biofilms used in this study were primarily composed of bacteria (most of them were rod-shaped) and pinnate diatoms (most of them were Nitzschia spp.), and their abundance varied widely among experimental repeats (Tables $1 \& 2$ ). For instance, the density of diatom cells in Day 3 biofilm was $\sim 3,34$ and 0 cells $\mathrm{mm}^{-2}$ in Experimental Repeat 1, 2 and 3, respectively (Table 1). Despite these variations, a significant positive linear correlation existed between biofilm age and abundance of both bacteria and diatoms (Table 3). A positive correlation was also found between decreasing intertidal height (high to low) and abundance of both bacteria and diatoms, both in the Marina Cove and at the HKUST piers (Table 3).

\section{Biomass}

Biomass measurements indicate the changes in the organic matter of biofilm with intertidal height and age. Despite the apparent variations in biomass among the experimental repeats (Tables $1 \& 2$ ), the biomass linearly increased with both the increasing biofilm age (Table 3: Expt 1) and the decreasing intertidal height, both in the Marina Cove (Table 3: Expt 2A) and at the HKUST piers (Table 3: Expt 2B).

\section{Bacterial community profile}

The bacterial communities (hereafter referred to as 'community') in the biofilm samples of Expt 1 were grouped according to the biofilm age (Fig. 2). In $3 \mathrm{~d}$ old biofilms, several T-RFs were either absent, or were present with low peak area (low fluorescence intensity) when compared to $>6 \mathrm{~d}$ old biofilms (Fig. 3A). Conspicuously, the community in $6 \mathrm{~d}$ old biofilms had a unique T-RF (e.g. Peak 3 in Fig. 3B). The bacterial communities of 9 and 12 d old biofilms were much less distinct, both in terms of the number and the fluorescence intensity of T-RFs (Fig. 3C,D). In both Marina Cove and the HKUST piers (biofilm samples used for Expts 2 \& 3), the communities in mid- and low-intertidal biofilms were almost similar, but were different from that of the high intertidal biofilm (Figs. 4 \& 5). A distinctive community was observed in subtidal biofilms (Fig. 4). Although the communities varied with intertidal height, several T-RFs with intensive fluorescence were found in all biofilm samples, e.g. Peaks 7 and 10 in Fig. 6 and Peaks 5 and 10 in Fig. 7. The microbial abundance and biomass in high intertidal biofilms obtained from Marina Cove and the HKUST piers were not significantly different (ANOVA, p > 0.05), but bacterial community profiles differed markedly (Fig. 8).

Table 1. Expt 1. Mean $( \pm \mathrm{SD}, \mathrm{n}=3$ ) microbial (bacteria and diatoms) abundance on biofilmed (BF) and unfilmed (PS-C) polystyrene dishes of a test vessel after larval bioassay. Total biomass (mean $\pm \mathrm{SD}, \mathrm{n}=3$ ) of $0,3,6,9$ and $12 \mathrm{~d}$ old biofilm is also shown. Data presented for 3 experimental repeats (Repeats 1 to 3 ). ND: data were not collected

\begin{tabular}{|c|c|c|c|c|c|c|}
\hline \multirow[t]{2}{*}{ Treatments } & \multirow[t]{2}{*}{ Repeat no. } & \multicolumn{2}{|c|}{ No. of bacteria (cells $\mathrm{mm}^{-2}$ ) } & \multicolumn{2}{|c|}{ No. of diatoms (cells $\mathrm{mm}^{-2}$ ) } & \multirow{2}{*}{$\begin{array}{c}\text { Biomass }\left(\mathrm{mg} \mathrm{mm}^{-2}\right) \\
\text { BF }\end{array}$} \\
\hline & & $\mathrm{BF}$ & PS-C & $\mathrm{BF}$ & PS-C & \\
\hline \multirow[t]{3}{*}{ PS-C/PS-C } & 1 & $2127 \pm 11$ & $2126 \pm 257$ & ND & ND & ND \\
\hline & 2 & $2300 \pm 294$ & $2320 \pm 381$ & ND & ND & ND \\
\hline & 3 & $2573 \pm 115$ & $2300 \pm 452$ & ND & ND & ND \\
\hline \multirow[t]{3}{*}{ Day 3: BF/PS-C } & 1 & $3106 \pm 430$ & $1526 \pm 427$ & $2.9 \pm 0.9$ & $0.1 \pm 0.1$ & $0.16 \pm 0.10$ \\
\hline & 2 & $4480 \pm 1049$ & $1620 \pm 35$ & $33.6 \pm 9.2$ & $0.31 \pm 0.1$ & $0.17 \pm 0.06$ \\
\hline & 3 & $3033 \pm 577$ & $893 \pm 442$ & 0 & 0 & $0.07 \pm 0.07$ \\
\hline \multirow[t]{3}{*}{ Day 6: BF/PS-C } & 1 & $11920 \pm 3610$ & $5053 \pm 300$ & $125.4 \pm 37.5$ & $2.5 \pm 0.2$ & $0.58 \pm 0.15$ \\
\hline & 2 & $7000 \pm 529$ & $2240 \pm 441$ & $68.8 \pm 11.5$ & $0.9 \pm 0.7$ & $1.30 \pm 0.62$ \\
\hline & 3 & $9066 \pm 1724$ & $2166 \pm 750$ & $8.1 \pm 3.2$ & $0.2 \pm 0.1$ & $0.69 \pm 0.32$ \\
\hline \multirow[t]{3}{*}{ Day 9: BF/PS-C } & 1 & $6893 \pm 1293$ & $6493 \pm 1147$ & $201.3 \pm 35.1$ & $5.3 \pm 0.9$ & $2.29 \pm 1.86$ \\
\hline & 2 & $10600 \pm 3019$ & $1553 \pm 128$ & $151.8 \pm 11.6$ & $0.7 \pm 0.2$ & $9.84 \pm 3.78$ \\
\hline & 3 & $9666 \pm 1006$ & $4466 \pm 1665$ & $17.7 \pm 3.1$ & $1.1 \pm 0.4$ & $1.70 \pm 0.12$ \\
\hline \multirow[t]{3}{*}{ Day 12: BF/PS-C } & 1 & $14053 \pm 1431$ & $6133 \pm 520$ & $1110.1 \pm 34.9$ & $8.7 \pm 1.3$ & $10.77 \pm 5.27$ \\
\hline & 2 & $17680 \pm 4873$ & $8933 \pm 7585$ & $1178 \pm 55.4$ & $5.9 \pm 1.2$ & $21.36 \pm 1.43$ \\
\hline & 3 & $18133 \pm 2203$ & $5866 \pm 1665$ & $365.4 \pm 82.5$ & $3.2 \pm 0.7$ & $4.16 \pm 1.12$ \\
\hline
\end{tabular}


Table 2. Expt 2. Mean $( \pm \mathrm{SD}, \mathrm{n}=3$ ) microbial (bacteria and diatoms) abundance on biofilmed (BF) and unfilmed (PS-C) polystyrene dishes of a test and control vessels after larval bioassay. Total biomass (mean $\pm \mathrm{SD}, \mathrm{n}=3$ ) of biofilms originated from 3 intertidal heights (H: high; M: mid; L: low) at Marina cove (Expt 2A) and HKUST (Expt 2B) is also shown. Data presented for 3 experimental repeats (Repeats 1 to 3 ). ND: data were not collected

\begin{tabular}{|c|c|c|c|c|c|c|c|}
\hline \multirow[t]{2}{*}{ Expt } & \multirow[t]{2}{*}{ Treatment } & \multirow[t]{2}{*}{ Repeat no. } & \multicolumn{2}{|c|}{ No. of bacteria (cells $\mathrm{mm}^{-2}$ ) } & \multicolumn{2}{|c|}{ No. of diatoms (cells $\mathrm{mm}^{-2}$ ) } & \multirow{2}{*}{$\begin{array}{c}\text { Biomass }\left(\mathrm{mg} \mathrm{mm}^{-2}\right) \\
\text { BF }\end{array}$} \\
\hline & & & $\mathrm{BF}$ & PS-C & $\mathrm{BF}$ & PS-C & \\
\hline \multirow[t]{9}{*}{$2 \mathrm{~A}$} & $\mathrm{H}-\mathrm{BF} / \mathrm{PS}-\mathrm{C}$ & 1 & $4293 \pm 496$ & $1866 \pm 1222$ & 0 & 0 & $0.41 \pm 0.22$ \\
\hline & & 2 & $3560 \pm 510$ & $1900 \pm 360$ & 0 & 0 & $0.01 \pm 0.02$ \\
\hline & & 3 & $3753 \pm 150$ & $2400 \pm 341$ & 0 & 0 & $0.47 \pm 0.40$ \\
\hline & M-BF/PS-C & 1 & $15466 \pm 3330$ & $5666 \pm 416$ & $0.4 \pm 0.1$ & 0 & $0.45 \pm 0.25$ \\
\hline & & 2 & $6880 \pm 1270$ & $5720 \pm 243$ & $1.3 \pm 0.1$ & $0.2 \pm 0.1$ & $0.02 \pm 0.02$ \\
\hline & & 3 & $6520 \pm 605$ & $2420 \pm 69$ & $0.9 \pm 0.5$ & $0.1 \pm 0.1$ & $0.09 \pm 0.01$ \\
\hline & L-BF/PS-C & 1 & $24000 \pm 10023$ & $8200 \pm 871$ & $5.6 \pm 4.4$ & $0.2 \pm 0.2$ & $1.17 \pm 0.20$ \\
\hline & & 2 & $12026 \pm 1086$ & $5840 \pm 831$ & $34.2 \pm 10.8$ & $0.8 \pm 0.2$ & $0.85 \pm 0.31$ \\
\hline & & 3 & $17253 \pm 532$ & $3693 \pm 241$ & $14.8 \pm 11.3$ & $0.6 \pm 0.3$ & $0.63 \pm 0.41$ \\
\hline \multirow[t]{12}{*}{$2 \mathrm{~B}$} & $\mathrm{H}-\mathrm{BF} / \mathrm{PS}-\mathrm{C}$ & 1 & $3713 \pm 535$ & $2886 \pm 313$ & 0 & 0 & $0.58 \pm 0.33$ \\
\hline & & 2 & $4113 \pm 594$ & $2266 \pm 211$ & 0 & 0 & $0.04 \pm 0.03$ \\
\hline & & 3 & $4280 \pm 280$ & $3613 \pm 1383$ & 0 & 0 & $0.20 \pm 0.09$ \\
\hline & M-BF/PS-C & 1 & $6666 \pm 2174$ & $2913 \pm 767$ & $8.9 \pm 1.6$ & $0.2 \pm 0.1$ & $2.35 \pm 0.33$ \\
\hline & & 2 & $8240 \pm 1220$ & $3113 \pm 120$ & $6.1 \pm 2.5$ & $0.2 \pm 0.1$ & $0.08 \pm 0.06$ \\
\hline & & 3 & $14853 \pm 1789$ & $4813 \pm 1659$ & $20.7 \pm 7.5$ & $2.2 \pm 0.5$ & $1.32 \pm 0.55$ \\
\hline & L-BF/PS-C & 1 & $19013 \pm 3217$ & $6573 \pm 1514$ & $20.5 \pm 16.5$ & $1.2 \pm 0.9$ & $2.22 \pm 0.70$ \\
\hline & & 2 & $14746 \pm 561$ & $6013 \pm 823$ & $24.9 \pm 13.4$ & $0.4 \pm 0.1$ & $0.88 \pm 0.33$ \\
\hline & & 3 & $15413 \pm 532$ & $5226 \pm 748$ & $132.5 \pm 43.1$ & $5.4 \pm 2.6$ & $3.23 \pm 0.99$ \\
\hline & PS-C/PS-C & 1 & $3133 \pm 743$ & $3613 \pm 92$ & 0 & 0 & ND \\
\hline & & 2 & $3106 \pm 503$ & $3240 \pm 884$ & 0 & 0 & ND \\
\hline & & 3 & $2960 \pm 381$ & $2520 \pm 432$ & 0 & 0 & ND \\
\hline
\end{tabular}

Table 3. Results of correlation analysis run between 3 factors describing biofilm quantity (i.e. bacterial abundance, diatom abundance, and biomass) and biofilm age (Expt 1), biofilms originated from 3 intertidal heights (high, mid and low) in Marina Cove (Expt 2A) and HKUST (Expt 2B). $\mathrm{r}_{\mathrm{S}}$ : Spearman's rank correlation coefficient; all values are significant at the $\mathrm{p}<0.001$ level

\begin{tabular}{|c|c|c|c|c|c|c|}
\hline \multirow[t]{2}{*}{ Independent variables } & \multicolumn{2}{|c|}{ Expt 1} & \multicolumn{2}{|c|}{ Expt 2A } & \multicolumn{2}{|c|}{ Expt 2B } \\
\hline & $\mathrm{n}$ & $\mathrm{r}_{\mathrm{S}}$ & $\mathrm{n}$ & $\mathrm{r}_{\mathrm{S}}$ & $\mathrm{n}$ & $\mathrm{r}_{\mathrm{S}}$ \\
\hline Bacterial abundance & 36 & 0.84 & 27 & 0.64 & 27 & 0.89 \\
\hline Diatom abundance & 36 & 0.85 & 27 & 0.91 & 27 & 0.87 \\
\hline Biomass & 36 & 0.92 & 27 & 0.55 & 27 & 0.66 \\
\hline
\end{tabular}

unfilmed control, or 3 and 12 d old biofilms (Fig. 9, Table 4). However, for test vessels with 12 d old biofilms, heterogeneity $G$ was also significant, indicating a high variability among replicates.

\section{Expt 2}

Regardless of intertidal height ( $H, M, L)$, place of biofilm origin (Marina cove and the HKUST piers) and experimental repeats (1 to 3 ), cyprids attached preferen-

\section{Effects of spatial and temporal changes of biofilm on cypris attachment}

\section{Expt 1}

In test vessels with 6 and 9 d old biofilms, the divergence from 50:50 distributions was highly significant (Table 4). In other words, cyprids preferred biofilmed (6 and $9 \mathrm{~d}$ old) over unfilmed dishes for attachment (Fig. 9). The magnitude of difference in the percent attachment between $6 \mathrm{~d}$ old biofilmed and unfilmed dishes was ca. $47 \%$, whereas between $9 \mathrm{~d}$ old biofilmed and unfilmed dishes, it was ca. $22 \%$. Conversely, no such preference was observed in test vessels with an tially to biofilmed surfaces and strongly avoided unfilmed dishes, with 1 exception (Fig. 10, Table 4). Cyprids did not show preference for high intertidal biofilms of HKUST. In control vessels, cyprids attached with equal frequency on both sides of the unfilmed dishes (Table 4; the divergence from 50:50 distribution was not significant).

\section{Expt 3}

Cyprids showed equal preference to mid- and lowintertidal biofilms. However, there was a strong and significant preference to biofilms of mid-intertidal 


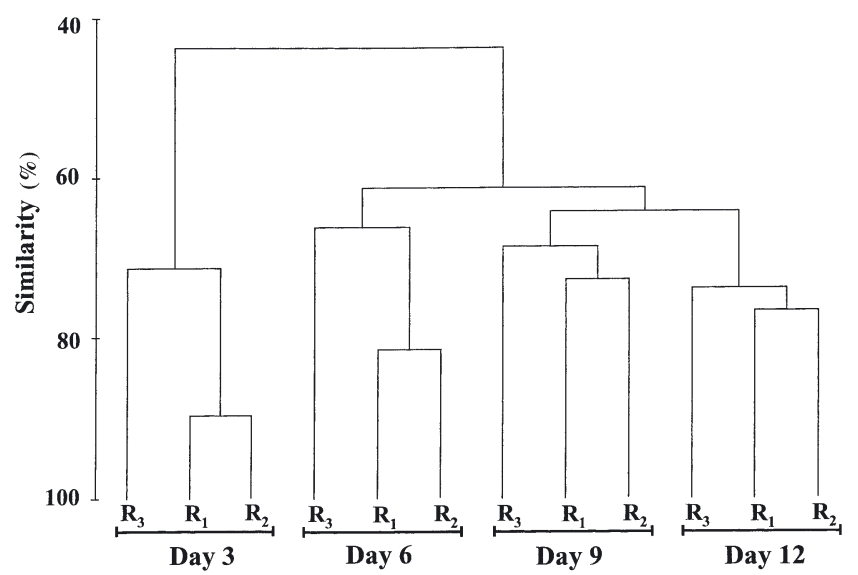

Fig. 2. Dendrogram compiled from cluster analysis of presence and absence data for the T-RFLP profiles of 3, 6, 9 and $12 \mathrm{~d}$ old biofilms (biofilm samples used for Expt 1). R: replicate sample, and the subscript number signifies replicate identity

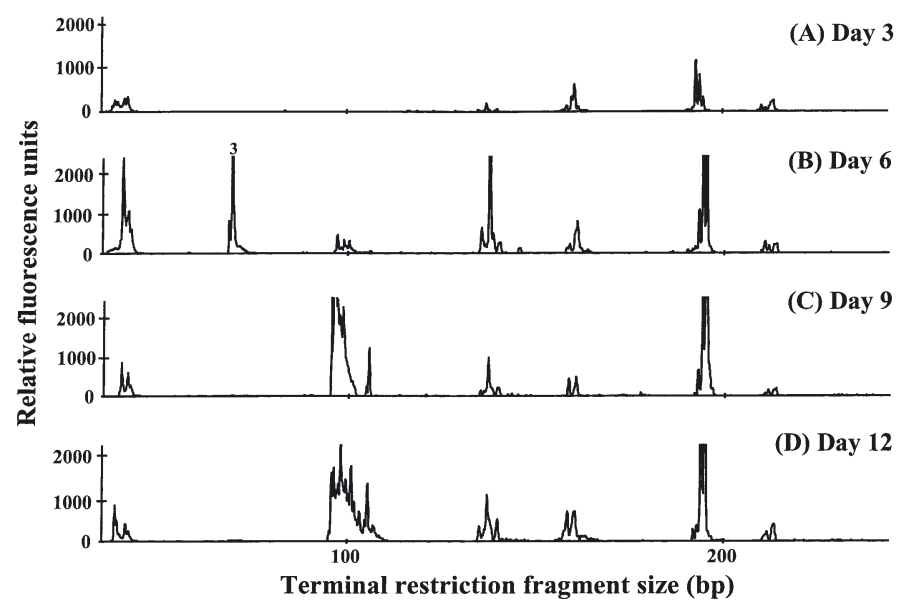

Fig. 3. T-RFLP profiles of 3, 6, 9 and $12 \mathrm{~d}$ old biofilms. Since all 3 replicate samples were clustered in 1 group (see Fig. 2), the TRFLP profile of 1 replicate sample (selected randomly) is shown

height when the cyprids were allowed to have an additional choice of biofilms from high or subtidal heights (Fig. 11, Table 4).

\section{Relationship between cypris attachment and various biofilm-related attributes}

In Expt 2, the 3 variables describing biofilm quantity (biomass, bacteria and diatom abundance) did not correlate significantly with percent attachment (Fig. 12). A similar trend was observed in Expt 1 (data not shown). In other words, variations in the abundance of microbial components (i.e. bacteria and diatoms) and biomass of biofilms in relation to intertidal height and

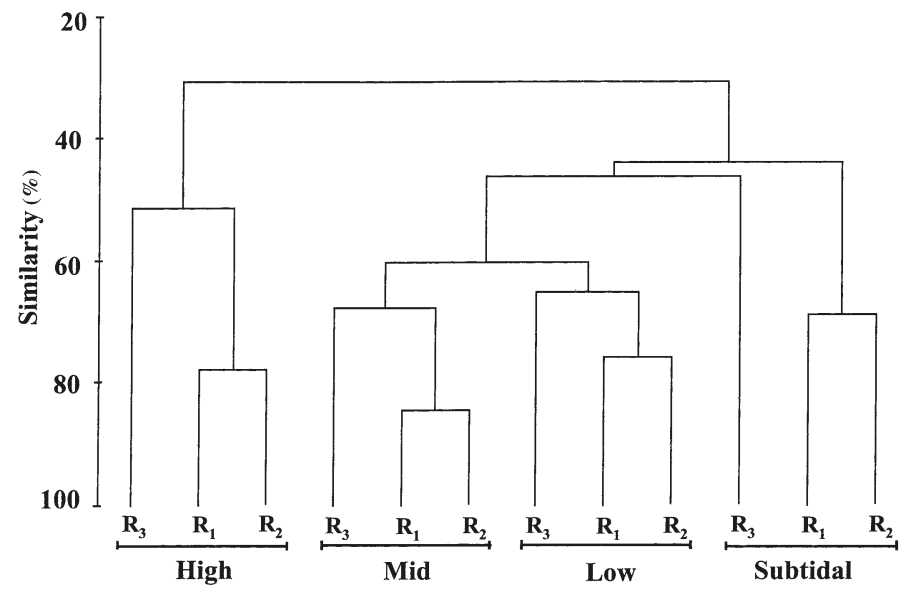

Fig. 4. Dendrogram compiled from cluster analysis of presence and absence data for the T-RFLP profiles of 3 intertidal (high, mid and low) and sublittoral biofilms of Marina cove, Hong Kong (biofilm samples used for Expts 2A and 3). $\mathrm{R}$ : replicate samples, and the subscript number signifies replicate identity

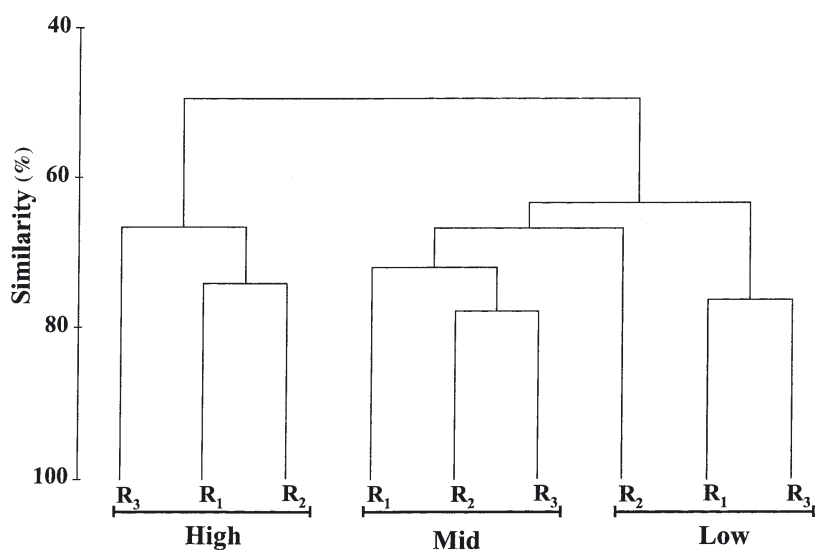

Fig. 5. Dendrogram compiled from cluster analysis of presence and absence data for T-RFLP profiles of 3 (high, mid and low) intertidal biofilms from The Hong Kong University of Science and Technology (HKUST) pier (biofilm samples used for Expt 2B). R: replicate samples, and the subscript number signifies replicate identity

age did not reflect differences in percent attachment. After the larval bioassay, few bacteria and diatoms were found on the initially unfilmed control dishes (Tables 1 \& 2). Nevertheless, the extent of such contamination was substantially low in most of the treatments used in this study. For instance, in Expt 1, the number of bacteria on the unfilmed dishes in 2-test vessels (Day 3 biofilm vs unfilmed control and Day 6 biofilm vs unfilmed control) was similar to the number of bacteria on the dishes in control vessels (ANOVA, p > 0.05). Owing to this low level of contamination, a distinctive attachment choice was verified in the majority of treatments. 


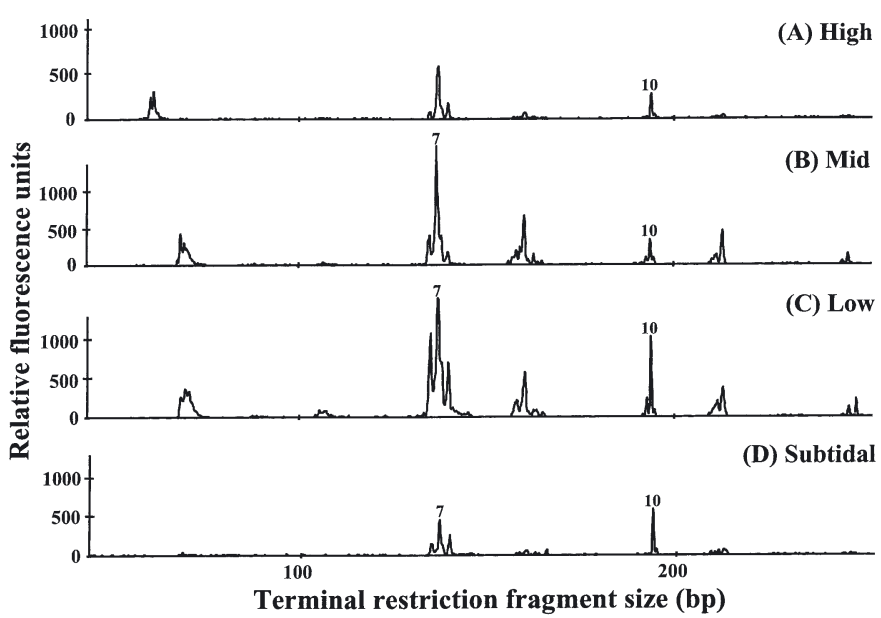

Fig. 6. T-RFLP profiles of 3 intertidal (high, mid and low) and sublittoral biofilms of Marina cove, Hong Kong. Since all the 3 replicate samples were clustered in 1 group (see Fig. 4), the T-RFLP profiles of 1 replicate sample (selected randomly) is shown

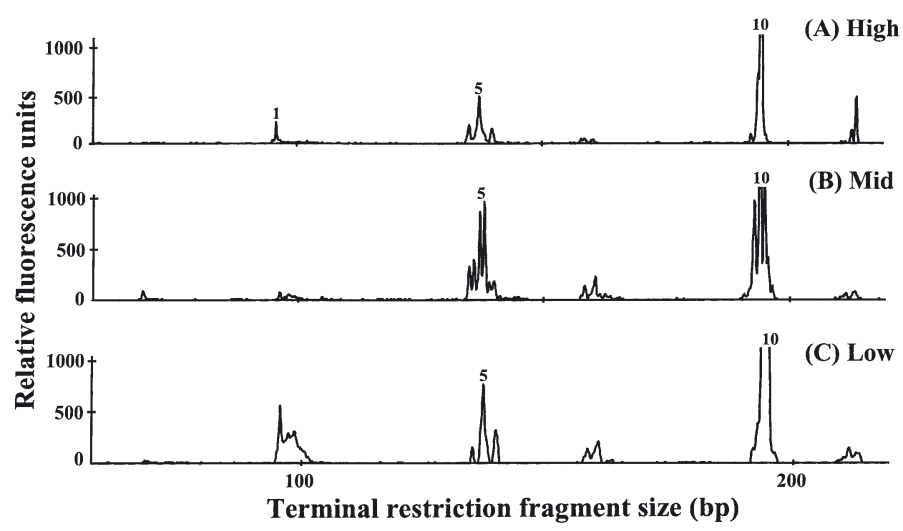

Fig. 7. T-RFLP profiles of 3 intertidal (high, mid and low) biofilms of The Hong Kong University of Science and Technology (HKUST) pier. Since all 3 replicate samples were clustered in 1 group (see Fig. 5), the T-RFLP profiles of 1 replicate sample (selected randomly) is shown

\section{DISCUSSION}

Biofilms have long been recognized as important modulators for the attachment of invertebrate larvae, and biofilm community structure has been hypothesized as one of the governing factors for the acceptance or rejection of biofilms by exploring larvae (e.g. Olivier et al. 2000, Lau et al. 2003). Although biofilm covers all submerged marine surfaces, the community structures of bacteria and diatoms in biofilm may vary substantially, both at spatial and temporal scales. The differences even at a microscopic scale can affect the surface attractiveness to settling marine-invertebrate

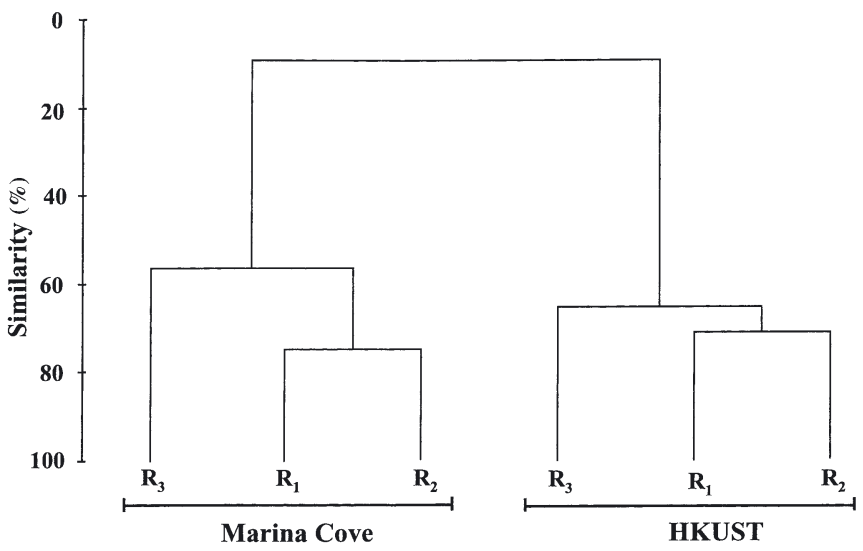

Fig. 8. Dendrogram compiled from cluster analysis of presence and absence data for the T-RFLP profiles of high intertidal biofilms from Marina cove and The Hong Kong University of Science and Technology (HKUST). R: replicate samples, and the subscript number signifies replicate identity

larvae, contributing to small-scale variations in recruitment pattern of marine organisms (see Raimondi 1988, Roberts et al. 1991, Wieczorek et al. 1996). Although many molecular tools have been developed to characterize microbial communities of different ecosystems, there has been no attempt so far to investigate the long-speculated correlation between larval attachment and microbial diversity in biofilms. Thus, this study is the first attempt to bridge the gap between larval biology and microbial ecology studies.

Microbial community structures of biofilms in this study were determined by 4 parameters: bacterial community profile, biomass, abundance of bacteria, and abundance of diatoms. Except for bacterial community profile, all other parameters are quantitative and correlated directly with the biofilms' time of exposure to seawater. Data of T-RFLP analysis on the bacterial community profile can be interpreted as 'semiquantitative' according to the number of peaks in each sample (i.e. number of distinguishable bacterial types), as well as qualitatively according to the position of peaks (i.e. occurrence of unique bacterial types). T-RFLP data can only be regarded as 'semiquantitative' since 1 peak may represent many species of bacteria that share the same cutting site for the chosen restriction enzyme (Liu et al. 1997). It should be noted that the intensity of individual peaks displayed in the electropherograms does not necessarily reflect the relative abundance of each bacterial type in the sample, due to possible differential amplification of DNA templates during PCR (Polz \& Cavanaugh 1998). For this reason, peak intensity data was not included in cluster analysis. Despite of these limitations, the technique is sensitive enough to detect differences in the bacterial communities developed in this study. Biofilm 
Table 4. Results of heterogeneity and log-likilihood ratio analysis used to test homogeniety among replicates, and to test preference among 2 surfaces offered (in test and control vessles) to cyprids in 3 experiments, consisting of 17 treatments, respectively. $p$-values are given with the degree of freedom $(v)$ in parentheses. The critical value for heterogeneity is $G_{\text {adj }}(0.05,14)=23.685$, and for log-likelihood test is $G_{\text {adj }}(0.05,1)=3.841 . G_{\text {adj }}$ : $G$ adjusted by Williams' correction. Significant values are showed in bold. The significant log-likelihood $G$-values indicate that cyprids preferentially attached on one side of the vessel. See Table 1 for abbrevations

\begin{tabular}{|c|c|c|c|c|c|}
\hline \multirow[t]{2}{*}{ Expt } & \multirow[t]{2}{*}{ Treatment } & \multicolumn{2}{|c|}{ Heterogeneity analysis } & \multicolumn{2}{|c|}{ Log-likelihood ratio test } \\
\hline & & $G_{\text {adj }}$ & $\mathrm{p}(\mathrm{v})$ & $G_{\text {adj }}$ & $p(v)$ \\
\hline \multirow[t]{5}{*}{1} & PS-C/PS-C & 18.279 & $>0.100(14)$ & 0.028 & $>0.750(1)$ \\
\hline & Day 3: BF/PS-C & 22.918 & $>0.050(12)$ & 3.598 & $>0.050(1)$ \\
\hline & Day 6: BF/PS-C & 17.669 & $>0.100(13)$ & 176.12 & $<0.001$ (1) \\
\hline & Day 9: BF/PS-C & 17.821 & $>0.050(11)$ & 28.329 & $<0.001$ (1) \\
\hline & Day 12: BF/PS-C & 35.038 & $<0.001(11)$ & 1.715 & $>0.100(1)$ \\
\hline \multirow[t]{4}{*}{$2 \mathrm{~A}$} & H-BF/PS-C & 21.706 & $>0.050$ (13) & 428.13 & $<0.001(1)$ \\
\hline & M-BF/PS-C & 19.473 & $>0.100(14)$ & 230.14 & $<0.001$ (1) \\
\hline & L-BF/PS-C & 22.219 & $>0.025(11)$ & 248.61 & $<0.001$ (1) \\
\hline & PS-C/PS-C & 20.019 & $>0.050(13)$ & 0.332 & $>0.500(1)$ \\
\hline \multirow[t]{4}{*}{$2 \mathrm{~B}$} & H-BF/PS-C & 8.839 & $>0.500(12)$ & 3.301 & $>0.050(1)$ \\
\hline & M-BF/PS-C & 20.939 & $>0.250(11)$ & 178.89 & $<0.001$ (1) \\
\hline & L-BF/PS-C & 17.003 & $>0.250(14)$ & 111.66 & $<0.001$ (1) \\
\hline & PS-C/PS-C & 20.019 & $>0.050(13)$ & 0.332 & $>0.500(1)$ \\
\hline \multirow[t]{4}{*}{3} & M-BF/H-BF & 16.971 & $>0.100(12)$ & 287.58 & $<0.001(1)$ \\
\hline & M-BF/L-BF & 24.212 & $<0.010(12)$ & 0.901 & $>0.250(1)$ \\
\hline & M-BF/S-BF & 16.042 & $>0.100(11)$ & 80.088 & $<0.001$ (1) \\
\hline & PS-C/PS-C & 20.019 & $>0.050(13)$ & 0.332 & $>0.500(1)$ \\
\hline
\end{tabular}

samples in this study were obtained from different tidal heights and were of different ages. These parameters can be regarded as indirect representations of the biofilms' total time of exposure to seawater, since biofilms from lower intertidal and subtidal regions were submerged in seawater for a longer period than those from higher tidal regions. In general, biomass and abundance of bacteria and diatoms were directly proportional to the biofilms' total time of exposure to seawater during pre-colonization. A similar trend was also observed for the complexity of bacterial community profile in the biofilms of different ages, but not for biofilms obtained from different tidal heights. Low- and mid-intertidal biofilms harbored the most complex bacterial community profile, but subtidal biofilms' profile was least complex. Biofilm community structures were also different in the different habitats (i.e. the Marina Cove and the HKUST pier), and varied with time (i.e. experimental repeats) and exposure duration of pre-colonization. These results indicate that the temporal and spatial variability of environmental factors such as tidal cycle, illumination, and nutrient availability can lead to the temporal and spatial variation of bacterial community structures of the biofilm. Since bacterial community structures can certainly affect the attractiveness of the biofilm to settling larvae (see discussion below), the temporal and spatial variation in biofilm community profile can lead to differential settlement of marine invertebrate larvae, and subsequently, a different recruitment pattern of the organisms on a microscopic scale.

In general, cyprids preferred to settle on biofilmed as opposed to unfilmed dishes (Figs. 9 \& 10), which was consistent with our early observations, in which cyprids also showed a clear preference to settling on the biofilmed over the clean surface (Harder et al. 2001). However, this contrasts with other observations (e.g. Olivier et al. 2000), in which cyprids were found to prefer the unfilmed over the filmed surface. When given choices of 2 biofilms from different tidal heights, cyprids either preferred to settle on mid-intertidal biofilms, or could not distinguish between mid- and low-intertidal biofilms (Fig. 11). Furthermore, cypris preference for biofilmed surfaces varied with the age of biofilm. Cyprids preferred moderately aged biofilms (i.e. 6 and 9 d) over the unfilmed control, whereas no such preference was found in either young or very old biofilms (i.e. 3 and $12 \mathrm{~d}$ ). The microbial biomass in $3 \mathrm{~d}$ old biofilm may not have reached the threshold level to induce cypris attachment. Though the bacterial community profiles for 9 and $12 \mathrm{~d}$ old biofilms were found to be similar, cyprids preferred only $9 \mathrm{~d}$ old biofilm, and showed no preference towards $12 \mathrm{~d}$ old biofilm. This lack of preference towards $12 \mathrm{~d}$ old biofilm could have resulted because the inductive effect of bacterial community in $12 \mathrm{~d}$ old biofilm might have been nullified by other microbial components, such as diatoms, cyanobacteria, etc. The percentage of cypris attachment was also found to be low in test vessels with 12 d old biofilm (see Fig. 9).

In all bioassays, cypris attachment did not correlate with microbial abundance (i.e. biomass, bacterial and diatom abundance) (Fig. 12). Diatoms seemed not to be a cue for cypris attachment, since cyprids settled heavily on biofilms devoid of diatoms (e.g. high- and midintertidal biofilms from the Marina Cove; Fig. 10). We speculate that the bacterial community profile in biofilms plays a significant role in causing a cypris attachment response to mid-intertidal biofilms. The following observations support our argument: (1) the occurrence of distinctive bacterial types coincided with the cyprids' strong preference of mid-intertidal biofilms, and (2) bacterial community profiles in midand low-intertidal biofilms shared a relatively high 

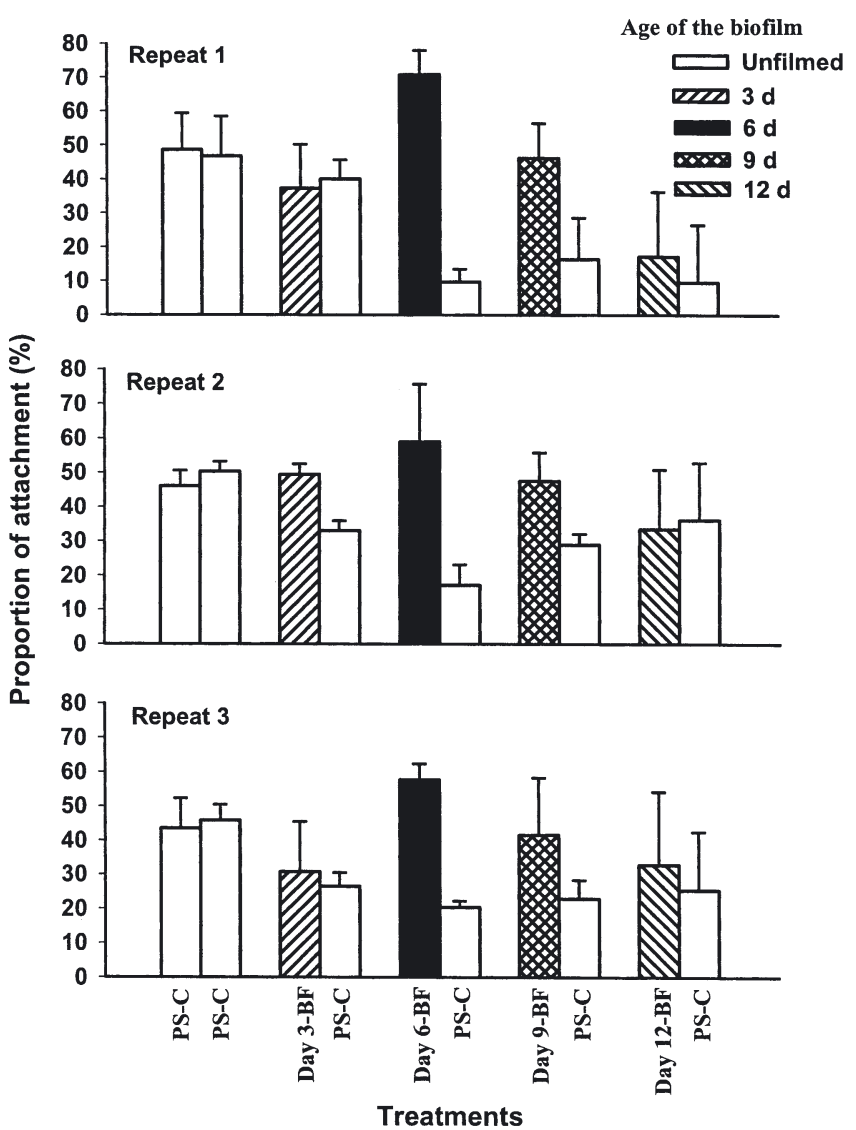

Fig. 9. Balanus amphitrite. Expt 1: attachment response of $B$. amphitrite cyprids to biofilm age in 3 experimental repeats. Each test vessel (treatment) consisted of biofilmed (BF) and unfilmed (PS-C) polystyrene dishes. Data are means $( \pm \mathrm{SD})$ of 5 replicate vessels

degree of similarity (ca. $60 \%$ ), which could possibly explain the cyprids' inability to distinguish between them in bioassays (Fig. 11). It appears that the current findings contradict the results of several previous studies investigating cypris attachment on bacteria isolated from biofilms (e.g. Maki et al. 1988, Avelin Mary et al. 1993, Lau et al. 2003), in which bacteria only exerted inhibitive effects or were neutral to cypris attachment. However, this sort of discrepancy may be more easily discussed from a microbiological point of view.

It is well known to microbiologists that most of the bacteria $(<95 \%)$ from natural environmental samples are non-cultivable by current technology (e.g. Ward et al. 1990). As indicated by many microbiological studies, cultivable bacteria are usually silent (i.e. functionally inactive) minorities in the natural environment, but can adapt to laboratory culture conditions extremely well (Eilers et al. 2000). In other words, bacteria involved in previous cypris attachment studies were only a minor, and possibly functionally insignificant, subset of those present in the marine environ- ment. Vibrio spp., Pseudoalteromonas spp., Alteromonas spp. and Bacillus spp., which have been used frequently in larval bioassays, may belong to this subset (Avelin Mary et al. 1993, Lau et al. 2003). The role of the non-cultivable majority of the bacterial population has not been investigated at all.

Without reliance on cultivation, molecular tools can unravel natural bacterial diversity and community profile by analyzing DNA extracted from environmental samples. Coupling molecular tools with larval settlement bioassays will allow investigators to evaluate the role of non-culturable bacteria in the modulation of larval settlement. Among a variety of molecular tools, we started with T-RFLP due to its simple operation with an automated genetic analyzer. It shall also provide sufficient information for revealing the bacterial community structural differences among environmental samples. Since T-RFLP analysis does not allow for the identification of bacteria in samples, investigators who are inter-
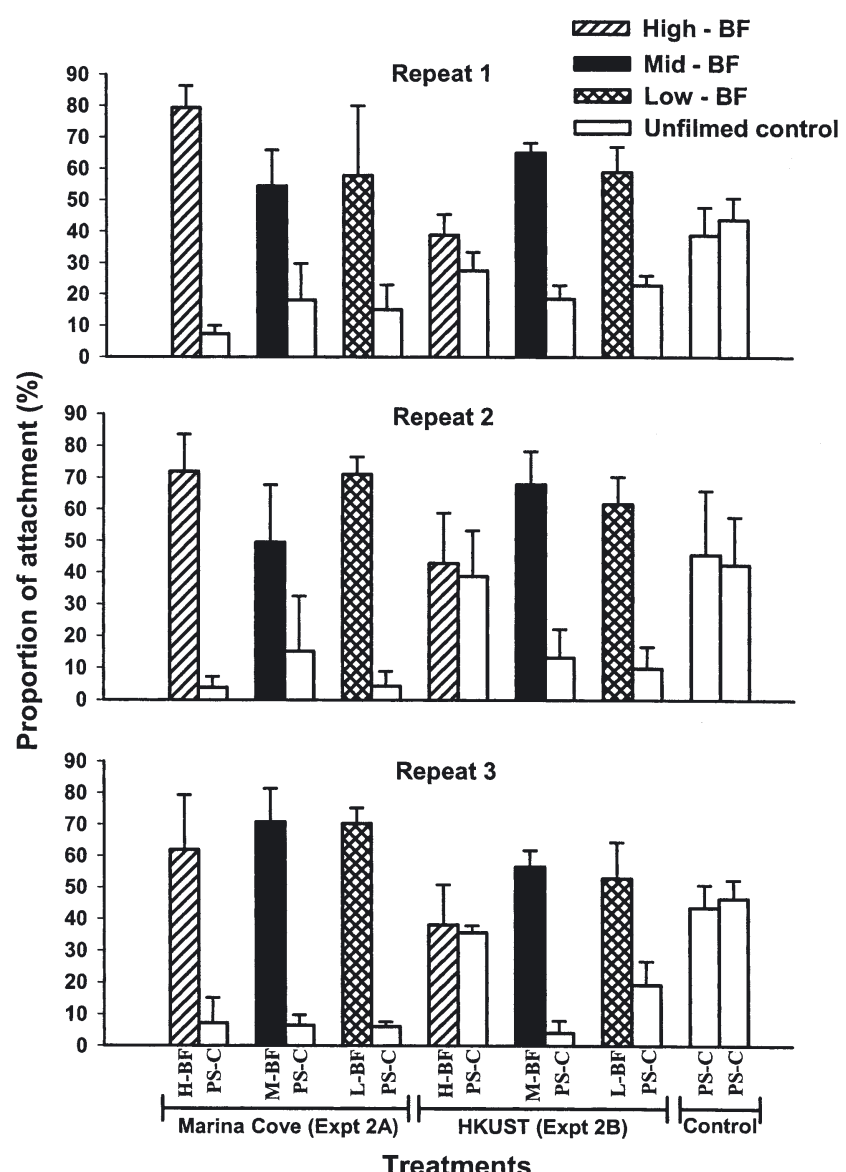

Fig. 10. Balanus amphitrite. Expt 2: attachment response of B. amphitrite cyprids to 3 intertidal biofilms (H: high; M: mid; L: low) in 3 experimental repeats. Each test vessel (treatment) consisted of biofilmed (BF) and unfilmed (PS-C) polystyrene dishes. Control vessels consisted of 2 unfilmed dishes. Data are means $( \pm \mathrm{SD})$ of 5 replicate vessels 
ested in this need to choose other techniques, such as denaturing gradient gel electrophoresis (DGGE; Muyzer et al. 1993), that allow for the extraction and sequence of DNA bands resolved on the gel. It shall be noted that fingerprinting techniques such as T-RFLP and DGGE may not detect minority bacterial populations, since template DNA from these populations represents a small fraction of the total extracted DNA, and may not be amplified by PCR due to kinetic bias (see Liu et al. 1997 and references therein). Nevertheless, T-RFLP and DGGE shall serve as powerful tools in detecting the bacterial community structural differences among environmental samples, and for studying the relationship between bacterial community dynamics of biofilm and the biofilms' attractiveness to settling larvae of marine invertebrates.

How do cyprids recognize the mid-intertidal biofilms in the field? There are 3 possibilities according to Thompson et al. (1998): firstly, the conspecifics present
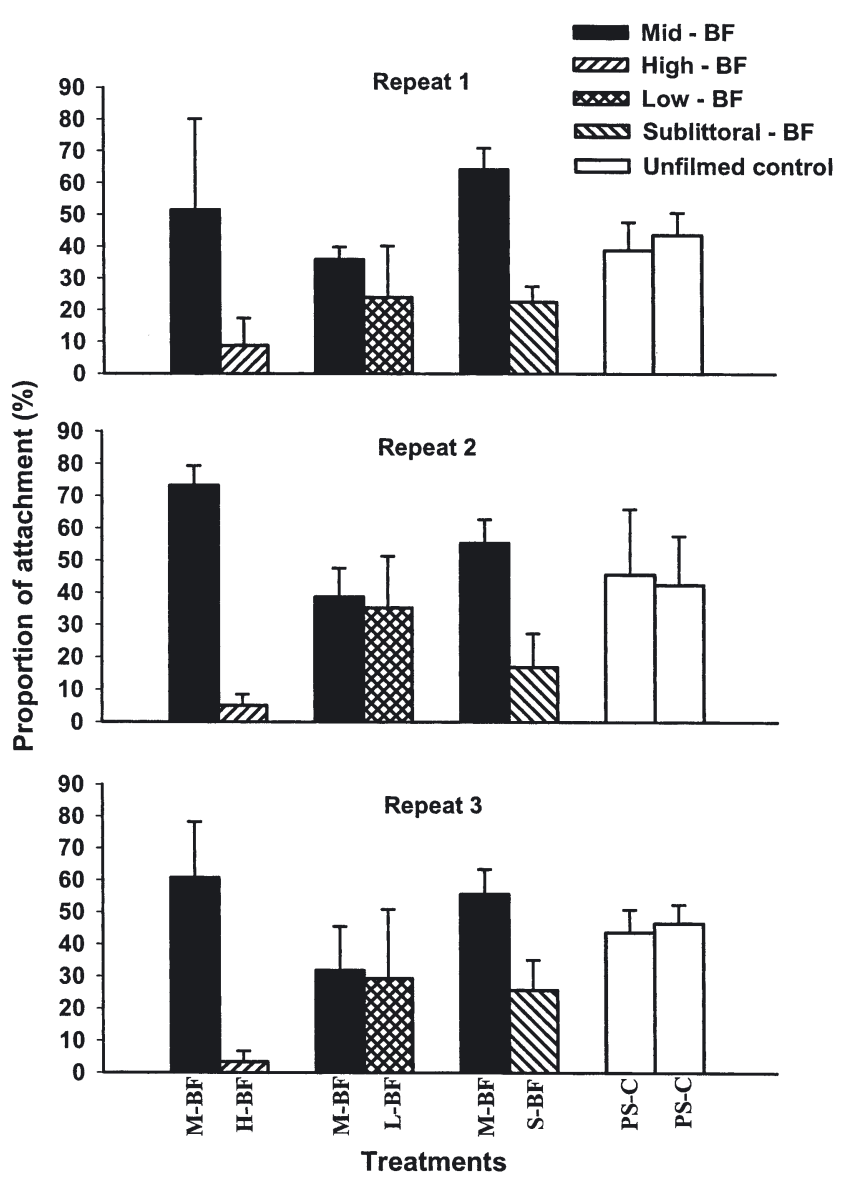

Fig. 11. Balanus amphitrite. Expt 3: attachment response of $B$. amphitrite cyprids to mid-intertidal biofilm (M-BF) in test vessels, which consisted of either high (H-BF), low (L-BF) or sublittoral (S-BF) biofilms as a choice in 3 experimental repeats. The control vessel consisted of 2 polystyrene unfilmed dishes (PS-C). Data are means $( \pm \mathrm{SD})$ of 5 replicate vessels
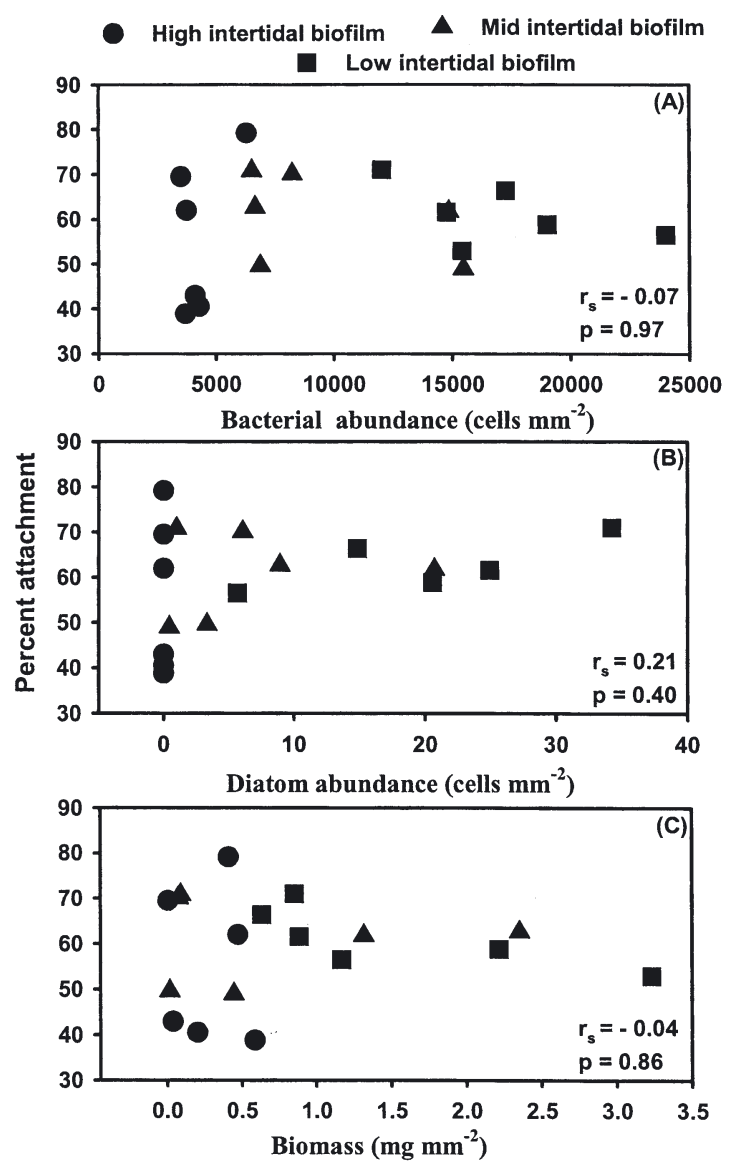

Fig. 12. Balanus amphitrite. Relationship between the attachment of $B$. amphitrite cyprids and (A) abundance of bacteria, (B) abundance of diatoms, and (C) biomass of biofilm. Mean $(\mathrm{n}=5)$ percent attachment on biofilmed dishes of 18 treatments ( 3 intertidal biofilms $\times 2$ sites $\times 3$ experimental repeats) in Expt 2 was plotted on the $y$-axis. Mean $(n=3)$ values of biomass and the abundance of bacteria and diatoms of biofilms used in the above 18 treatments were plotted on the $x$-axis. $\mathrm{r}_{\mathrm{S}}$ : Spearman's rank correlation coefficient

in the biofilm at that tidal height might have enhanced the attachment; secondly, due to the concentration of attachment-inducing cues by biofilms at that tidal height; thirdly, some characteristic of the microbial community at that tidal height might have provided the stimuli. According to our results, the first possibility is unlikely, since none of the biofilms used in this study had conspecifics. We have presented no evidence as to whether the concentration of inducing cues by the biofilms was involved, although it is unlikely because all these biofilms were developed near the conspecifics (i.e. biofilms used in Expt 3). According to our results, it is possible that a distinctive bacterial community profile specific to mid-intertidal height might have been involved. Though our laboratory experiments provided a controlled environment in assessing the roles of biofilm 
on the cypris attachment, considerable care must be exercised in extrapolating laboratory results to the field condition where the attachment can be influenced by factors such as the presence of conspecifics, and cyprids' physiological condition (see 'Introduction').

In summary, our results show that cyprids preferred to settle on (1) intertidal biofilms (i.e. $6 \mathrm{~d}$ old) over unfilmed surface, and (2) biofilms of mid-intertidal height over high-intertidal or subtidal heights. There was no correlation between the 3 biofilm attributes (i.e. biomass, abundance of bacteria and diatoms) and cypris attachment. However, it appears that changes in bacterial community profile of the biofilm can significantly affect its attractiveness to barnacle larvae (accepting or rejecting a surface) of settling larvae. We hypothesize that temporal and spatial changes in microbial community profile lead to a temporal and spatial recruitment pattern of marine invertebrates at a microscopic scale in the natural environment.

Acknowledgements. We wish to thank M. M. Y. Tsoi for assistance in T-RFLP analysis. The authors are grateful to T. Harder, S. Dobretsov and D. Hans for productive discussions during the course of this work. Thanks are due to L. Soo and Y. $\mathrm{K}$. Tam for assistance in algal cultures and TOC analysis, respectively. This work was supported by RGC grants (CA00/01.SC01, HKUST6119/01M, HKUST6100/02M, HKUST 6281/03M) to P.-Y.Q.

\section{LITERATURE CITED}

Avelin Mary Sr, Vitalin Mary Sr, Rittschof D, Nagabhushanam R (1993) Bacterial-barnacle interaction: potential of using juncellins and antibiotics to alter structure of bacterial communities. J Chem Ecol 19:2155-2167

Clarke KR, Warwick RM (1994) Changes in marine communities. Bourne Press, Plymouth

Eilers H, Pernthaler J, Glöckner FO, Amann R (2000) Culturability and in situ abundance of pelagic bacteria from the North Sea. Appl Environ Microbiol 66:3044-3051

Harder T, Thiyagarajan V, Qian PY (2001) Effect of cyprid age on the settlement of Balanus amphitrite Darwin in response to natural biofilms. Biofouling 17:211-219

Harder T, Lau SCK, Dobretsov S, Fang TK, Qian PY (2003) A distinctive epibiotic bacterial community on the soft coral Dendronephthya sp. and antibacterial activity of coral tissue extracts suggest a chemical mechanism against bacterial epibiosis. FEMS Microbiol Ecol 43: 337-347

Henschel JR, Cook PA (1990) The development of a marine fouling community in relation to the primary film of microorganisms. Biofouling 2:1-11

Holm ER, McClare M Jr, Rittschof D (2000) Variation in attachment of the barnacle Balanus amphitrite: sensation or something else? Mar Ecol Prog Ser 202:153-162

Holmstrom C, Rittschof D, Kjelleberg S (1992) Inhibition of settlement of larvae of Balanus amphitrite and Ciona intestinalis by a surface-colonizing marine bacterium. Appl Environ Microbiol 58:2111-2115

Hudon C, Bourget E, Legendre P (1983) An integrated study of the factors influencing the choice of the settling site of
Balanus crenatus cyprid larvae. Can J Fish Aquat Sci 40: 1186-1194

Jeffery CJ (2002) New settlers and recruits do not enhance settlement of a gregarious intertidal barnacle in New South Wales. J Exp Mar Biol Ecol 275:131-146

Lau SCK, Thiyagarajan V, Qian PY (2003) The bioactivity of bacterial isolates in Hong Kong waters for the inhibition of barnacle (Balanus amphitrite Darwin) settlement. J Exp Mar Biol Ecol 282:43-60

Liu WT, Marsh TL, Cheng H, Forney LJ (1997) Characterization of microbial diversity by determining terminal restriction fragment length polymorphisms of genes encoding 16S rRNA. Appl Environ Microbiol 63:4516-4522

Maki JS, Rittschof D, Costlow JD, Mitchell R (1988) Inhibition of attachment of larval barnacles, Balanus amphitrite, by bacterial surface films. Mar Biol 97:199-206

Minchinton TE, Scheibling RE (1993) Variations in sampling procedure and frequency affect estimates of recruitment of barnacles. Mar Ecol Prog Ser 99:83-88

Miron G, Boudreau B, Bourget E (1999) Intertidal barnacle distribution: a case study using a multiple working hypothesis. Mar Ecol Prog Ser 189:205-219

Muyzer G, DeWaal EC, Uitterlinden AG (1993) Profiling of complex microbial populations by denaturing gradient gel electrophoresis analysis of polymerase chain reactionamplified genes coding for 16S rRNA. Appl Environ Microbiol 59:695-700

O'Connor NJ, Richardson DL (1996) Effects of bacterial films on attachment of barnacle (Balanus improvisus Darwin) larvae: laboratory and field studies. J Exp Mar Biol Ecol 206:69-81

O'Connor NJ, Richardson DL (1998) Attachment of barnacle (Balanus amphitrite Darwin) larvae: responses to bacterial films and extracellular materials. J Exp Mar Biol Ecol 226: 115-129

Olivier F, Tremblay R, Bourget E, Ritschoff D (2000) Barnacle settlement: field experiments on the influence of larval supply, tidal level, biofilm quality and age on Balanus amphitrite cyprids. Mar Ecol Prog Ser 199:185-204

Osborn AM, Moore ERB, Timmis KN (2000) An evaluation of terminal-restiction fragment length polymorphism (T-RFLP) analysis for the study of microbial community structure and dynamics. Environ Microbiol 2:39-50

Polz MF, Cavanaugh CM (1998) Bias in template-to-product ratios in mutlitemplate PCR. Appl Environ Microbiol 64: 3724-3730

Qiu JW, Thiyagarajan V, Leung AWY, Qian PY (2003) Development of a marine subtidal epibiotic community in Hong Kong: implications for deployment of artificial reefs. Biofouling 19:37-46

Raimondi PT (1988) Settlement cues and determination of the vertical limit of an intertidal barnacle. Ecology 69:400-407

Roberts D, Rittschof D, Holm E, Schmidt AR (1991) Factors influencing initial larval settlement: temporal, spatial and surface molecular components. J Exp Mar Biol Ecol 150: 203-211

Steinberg PD, Nys RD, Kjelleberg S (2002) Chemical cues for surface colonization. J Chem Ecol 28:1935-1951

Strathmann RR, Branscomb ES, Vedder K (1981) Fatal errors in set as a cost of dispersal and the influence of intertidal flora on set of barnacles. Oecologia 48:13-18

Thiyagarajan V, Harder T, Qian PY (2002) Effect of the physiological condition of cyprids and laboratory-mimicked seasonal conditions on the metamorphic successs of Balanus amphitrite Darwin (Cirripedia; Thoracica). J Exp Mar Biol Ecol 274:65-74

Thomason JC, Hills JM, Clare AS, Neville A, Richardson M 
(1998) Hydrodynamic consequences of barnacle colonization. Hydrobiologia 375:1-21

Tsurumi K, Fusetani N (1998) Effects of early fouling communities formed in the field on settlement and metamorphosis of cyprids of the barnacle, Balanus amphitrite Darwin. Biofouling 12:119-131

Wahl M, Hoppe K (2002) Interactions between substratum rugosity, colonization density and periwinkle grazing efficiency. Mar Ecol Prog Ser 225:239-249

Ward DM, Weller R, Bateson MM (1990) 16S rRNA sequences reveal numerous uncultured microorganisms in a natural

Editorial responsibility: John Dolan,

Villefranche-sur-Mer, France community. Nature 345:63-65

Wieczorek SK, Todd CD (1998) Biofilm cues and larval settlement. Biofouling 12:81-118

Wieczorek SK, Clare AS, Todd CD (1995) Inhibitory and facilitatory effects of microbial films on settlement of Balanus amphitrite amphitrite larvae. Mar Ecol Prog Ser 119: 221-228

Wieczorek SK, Murray AWA, Todd CD (1996) Biofilm cues and larval settlement. Biofouling 10:309-330

Zar JH (1999) Biostatistical analysis, 4th edn. Prentice Hall, Englewood Cliffs, NJ

Submitted: March 22, 2002; Accepted: July 16, 2003

Proofs received from author(s): October 16, 2003 